ISSN 0258-7122 (Print), 2408-8293 (Online)

Bangladesh J. Agril. Res. 41(4): 725-734, December 2016

\title{
EFFICACY OF SOME NEW GENEARATION INSECTICIDES AND A BOTANICAL AGAINST MUSTARD APHID AND THEIR TOXICITY TO COCCINELLID PREDATORS AND FORAGING HONEYBEES
}

\author{
N. K. DUtTA ${ }^{1}$, S. N. Alam² ${ }^{2}$ M. MAHMUdUnNABI ${ }^{3}$ \\ M. F. KHATUN ${ }^{4}$ AND Y. J. KWON ${ }^{5}$
}

\begin{abstract}
Field studies were carried out to evaluate the efficacy of four new generation insecticides along with a botanical against mustard aphid (Lipaphis erysimi Kalt.) and their toxicity to coccinellid beetles and foraging honeybees during 2014-15 at Bangladesh Agricultural Research Institute (BARI), Gazipur, Bangladesh. Buprofezin 40 SC was found to be the most effective against aphid offering the lowest aphid population (1.56/ top $10 \mathrm{~cm}$ central twig) at 7 days after spraying (DAS) which was statistically identical to Diafenthiuron 500SC (1.85/ top10cm central twig). Among the treatments, Azadiractin 1EC appeared to be safest to coccinellid beetles and foraging honeybees because it recorded the highest number of beetle (7.50/5 plants) and honeybee $(9.64 / \mathrm{plot} / 5 \mathrm{~min})$ population at $7 \mathrm{DAS}$, although honeybee population did not vary statistically with that of Buprofezin 40 SC and Lufenuron 5EC treated plots. Indoxacarb $145 \mathrm{SC}$ was found to be the most toxic against honeybees. However, the highest yield was obtained from Buprofezin $40 \mathrm{SC}\left(1.57 \mathrm{t} \mathrm{ha}^{-1}\right)$ treated plot although this was statistically identical to that Diafenthiuron 500SC $\left(1.52 \mathrm{t} \mathrm{ha}^{-1}\right)$ and Azadiractin 1EC $\left(1.48 \mathrm{t} \mathrm{ha}^{-1}\right)$ treated plots.
\end{abstract}

Keywords: Mustard aphid, Predators, honeybee, insecticides, neem product.

\section{Introduction}

Rapeseed-mustard (Brassica rapa) is an important oil crop and constitute the major source of edible oil in Bangladesh. But its production is seriously impeded due to attack of various insect-pests. The crop is prone to be attacked by number of insect pests (Rai, 1976). More than three dozen of pests are known to be associated with various phenological stages of rapeseed and mustard crops in India (Bakhetia et al., 1989). Among the insect pests, aphid, Lipaphis erysimi (Kalt.) is a serious insect pest, infesting the crop right from seedling stage to maturity but that ravages the crop during the reproductive phase and act as a limiting factor in the production. The infestation of pest not only results in reduced yield of the seeds but also reduces the oil content upto $66.87 \%$ (Singhvi et al., 1973). Besides these, aphids secrete honeydew, which encourage the

\footnotetext{
${ }^{1,2 \& 3}$ Entomology Division, Bangladesh Agricultural Research Institute (BARI), Gazipur, ${ }^{4}$ Department of Entomology, Bangabandhu Sheikh Mujibur Rahman Agricultural University (BSMRAU), Gazipur, Bangladesh, ${ }^{5}$ School of Applied Biosciences, Kyungpook National University, Daegu, Korea.
} 
growth of the sooty moulds giving the stem and leaves black appearance and interfere the photosynthesis.

Attempts to suppress aphids currently entail excessive use of insecticides by the farmers. Indiscriminate use of insecticides pose some hazardous effects, such as development of insecticide resistance in insect pests, adverse effects on friendly organisms, environmental pollution and accumulation of toxic elements in food and ultimately pesticide residue-induced diseases in human beings (Ambethger, 2009). Meanwhile, the use of new generation insecticides or botanical insecticide could be considered as possible alternative for suppressing aphid because these are claimed to be relatively safer or have little impact on beneficial organisms compared to other conventional insecticides, and they have attracted considerable attention for their inclusion in IPM programs. Moreover, some insect growth regulators (IGRs) are presently available which are also considered as new generation insecticides. IGRs are generally low in toxicity to humans and environment. IGRs generally suppress insects either through disruption of metamorphosis or interference with reproduction (Riddiford and Truman, 1978).

Coccinellid beetles (Lady birds), Ccocinella septempunctata are the important entomophagous predators against many species of aphids and observed as an efficient and mightiest predator of L. erysimi in field conditions (Singh and Singh 2013). Honeybees are primary pollinators of mustard crop and hence they are important to increase productivity of mustard crop (Hayter and Cresswell 2006). However, there are few studies about the side effects of the new generation insecticides on predatory arthropods such as ladybirds and foraging honey bee.

Keeping this in view, the present studies were undertaken to evaluate some new generation and a botanical against aphids attacking mustard and their relative toxicity to coccinellid predators and foraging honeybees.

\section{Materials and Method}

\section{Experimental design and layout}

The research was carried out in experimental field of Bangladesh Agricultural Research Institute (BARI) during 2014-15.The land was well prepared by ploughing followed by laddering to ensure proper growth of mustard. The experiment was conducted in a complete randomized block design with 3 replications having plot size of $4 \times 3 \mathrm{~m}$ and spacing between row to row and plant to plant as $30 \mathrm{~cm}$ and $10 \mathrm{~cm}$, respectively. The mustard cultivar BARI- Sarisha 14 was sown on November 10, 2014. There were five treatments including untreated control. Four new generation insecticides, Buprofezin 40SC, Indoxacarb 145SC, Lufenuron $5 \mathrm{EC}$ and Diafenthiuron 500SC along with a with botanical, Azadiractin 1EC were evaluated to see their effectiveness against mustard aphid and relative toxicity to coccinellid predator and foraging honeybee. Details of the 
treatments are given in Table 1. The test insecticides were applied twice as foliar spray with the help of an air compression high volume sprayer at spray volume rate of $500 \mathrm{~L} \mathrm{ha}^{-1}$. The first spray of insecticides was given when the aphid population reached ETL of 50 per plant (Bath \& Singh, 1989) and second after an interval of 10 days. During spraying application care was taken to maintain the distance of $25 \mathrm{~cm}$ between the nozzle and plant parts in order to avoid plant damage due to strong spray fluid. The whole plant was thoroughly covered by spray fluid. Sprayer was washed and cleaned after each insecticide spray. All the standard agronomic practices were followed to raise a good crop. Manures and fertilizers were applied as per recommended dose.

Table 1. Details of the insecticides/treatments used in the experiment.

\begin{tabular}{ccccc}
\hline Treatments & Trade name & Group/Class & Dose \\
\hline Buprofezin & Commando 40SC & $\begin{array}{c}\text { Thiadizine insect growth } \\
\text { regulator }\end{array}$ & $0.5 \mathrm{ml} \mathrm{l}^{-1}$ water \\
Indoxacarb & Forgun 145SC & $\begin{array}{c}\text { Oxadiazin derivative } \\
\text { Bufenuron }\end{array}$ & $1 \mathrm{ml} \mathrm{l}^{-1}$ water \\
Xenon 5EC & $\begin{array}{c}\text { Benzoylurea insect } \\
\text { growth regulator }\end{array}$ & $1 \mathrm{ml} \mathrm{l}^{-1}$ water \\
Diafenthiuron & Polo 500 SC & $\begin{array}{c}\text { Thiourea derivative } \\
\text { Azadiractin }\end{array}$ & Bioneem plus & Neem (Azadiractin \\
indica $)$ product & $1 \mathrm{ml} \mathrm{l}^{-1}$ water \\
Untreated control & 1EC & inater \\
(water spray only) & - & - & - \\
\hline
\end{tabular}

\section{Recording of data}

The observations on counts of aphid and coccinellid predator were recorded on 10 randomly selected plants per plot. On each plant, $10 \mathrm{~cm}$ top central twig were observed to record aphid, while for predators total numbers present in whole plant was recorded. The data on surviving aphid population was reported on the basis of mean aphid population per plant while predators were reported as mean population per five plants. Population of foraging honeybee was counted from whole plot during peak foraging time (11 a.m.) for 5 minutes and was reported as mean population per plot.

Precount observation of aphid, predator and honeybee was recorded one day before spraying and subsequent postcount data on 3 and 7 days after spraying (DAS) were also recorded. It is to be noted here that, one species of coccinellid beetles (Coccinella septempunctata) was noticed in the crop. On the other hand, three species (Apis mellifera, A. dorsata and A. cerena) of honeybee were observed but data were taken together as honeybees. Observations on phytotoxicity symptoms (crop injury) was taken visually on crop injury using 0 10 scale considering the following symptoms i.e. leaf injury on the tips and leaf 
surface, wilting, vein clearing, necrosis, epinasty and hyponasty. The seed yield from the each treated and untreated control plot was recorded.

\section{Statistical analysis}

Data were analyzed by using MSTAT-C software for analysis of variance following randomized completely block design (RCBD) and treatment means were separated by applying Duncan's Multiple Range Test (DMRT) at 5\% level of significance.

\section{Results and Discussion}

\section{A. Results}

\section{Efficacy of insecticidal treatments in reducing aphid infestation in mustard}

It is evident from Table 2 that all the insecticidal treatments were significantly superior to untreated control in reducing aphid population. At 3 days after spraying (DAS), Buprofezin showed the lowest population with 2.96 aphids/ top $10 \mathrm{~cm}$ central twig as against 22.88 aphids/ top10 cm (central twig) in untreated control. But Efficacy of buprofezin was statistically at par with Diafenthiuron. Buprofezin and Diafenthiuron was found to be the most effective against aphid upto 7 DAS. The effectiveness of botanical, Azadiractin 1EC was the next to Buprofezin and Diafenthiuron in reducing aphid population of mustard. Azadiractin 1EC recorded 6.22 and 5.21aphids/ top $10 \mathrm{~cm}$ (central twig), at $3 \mathrm{DAS}$ and $7 \mathrm{DAS}$, respectively but these were statistically at par with Indoxacarb treated plots. Among the tested insecticides Lufenuron performed least and recorded highest population of aphid both at 3 DAS (13.52aphids/ top $10 \mathrm{~cm}$ central twig) and 7 DAS(12.85 aphids/ top $10 \mathrm{~cm}$ central twig). Similarly, Percent reduction of aphid population over pretreated at 7 DAS was recorded as the highest from Buprofezin $(93.27 \%)$ followed by Diafenthiuron (92.57\%),while this was the lowest in untreated control $(3.34 \%)$ plot where only water was sprayed.

Table 2. Efficacy of different insecticidal treatments on the population reduction of aphid in mustard crop.

\begin{tabular}{l|c|c|c|c}
\hline \multirow{2}{*}{ Treatments } & \multicolumn{3}{|c|}{$\begin{array}{c}\text { Mean Aphid population/ top } 10 \mathrm{~cm} \\
\text { central twig of plant }\end{array}$} & $\begin{array}{c}\text { Percent reduction of } \\
\text { aphid population over } \\
\text { pretreated at 7 DAS }\end{array}$ \\
\cline { 2 - 4 } & $1 \mathrm{DBS}$ & $3 \mathrm{DAS}$ & $7 \mathrm{DAS}$ & 93.27 \\
\hline Buprofezin 40SC & 23.21 & $2.96 \mathrm{~d}$ & $1.56 \mathrm{~d}$ & 76.08 \\
Indoxacarb 145SC & 23.42 & $6.50 \mathrm{c}$ & $5.60 \mathrm{c}$ & 46.90 \\
Lufenuron 5 EC & 24.20 & $13.52 \mathrm{~b}$ & $12.85 \mathrm{~b}$ & 92.57 \\
Diafenthiuron 500SC & 24.91 & $3.21 \mathrm{~d}$ & $1.85 \mathrm{~d}$ & 77.55 \\
Azadiractin1EC & 23.21 & $6.22 \mathrm{c}$ & $5.21 \mathrm{c}$ & 3.34 \\
Untreated control & 24.25 & $22.88 \mathrm{a}$ & $23.44 \mathrm{a}$ & \\
(water spray only) & & & & \\
\multicolumn{1}{c}{ CV\% } & 11.96 & 13.09 & 16.65 & \\
\hline
\end{tabular}

Means having same letter(s) in a column are not significantly different at $\mathrm{P}>0.05$ followed by DMRT. DBS= Day Before spray; DAS= Days After Spray 


\section{Effect of different treatments on population of Coccinellid beetles, Coccinella septempunctata}

The results presented in Table 3 indicated that there were significant variations in beetle population in different treatments. At 3 DAS, among the treatments, significantly the highest population of coccinellid beetle was observed in plots treated with Azadiractin ( 7.12 beetles / 5 plants) which was followed by Buprofezin (5.62 beetles/ 5 plants). However, Coccinellid beetle population was statistically similar in Buprrofezin, Diafenthiuron, Lufenuron and Indoxacarb treated plots. The similar result was found at 7 DAS. Among the insecticides, the beetle population reduction over pretreated at 7 DAS was found highest $(63.69 \%)$ in Indoxacarb while this was the lowest in Azadiractin 1EC (36.06\%) treated plots.

Table 3. Efficacy of different insecticidal treatments on the population reduction of coccinellid beetles in mustard crop.

\begin{tabular}{l|c|c|c|c}
\hline \multirow{2}{*}{ Treatments } & \multicolumn{3}{|c|}{$\begin{array}{c}\text { Mean coccinellid beetle } \\
\text { population/5 plants }\end{array}$} & $\begin{array}{c}\text { Percent reduction of } \\
\text { coccinellid beetle population } \\
\text { over pretreatment at 7 DAS }\end{array}$ \\
\cline { 2 - 4 } & $1 \mathrm{DBS}$ & $3 \mathrm{DAS}$ & $7 \mathrm{DAS}$ & 52.63 \\
\hline Buprofezin 40SC & 11.02 & $5.62 \mathrm{c}$ & $5.22 \mathrm{c}$ & 63.69 \\
Indoxacarb 145SC & 10.88 & $3.95 \mathrm{c}$ & $3.65 \mathrm{c}$ & 55.42 \\
Lufenuron 5 EC & 11.26 & $5.21 \mathrm{c}$ & $5.02 \mathrm{c}$ & 52.24 \\
Diafenthiuron 500SC & 10.68 & $5.01 \mathrm{c}$ & $5.10 \mathrm{c}$ & 29.38 \\
Azadiractin1EC & 10.62 & $7.12 \mathrm{~b}$ & $7.50 \mathrm{~b}$ & 0.87 \\
Untreated control & 10.82 & $10.28 \mathrm{a}$ & $10.42 \mathrm{a}$ & - \\
(water spray only) & & & & \\
CV(\%) & 8.97 & 14.41 & 15.31 & $\mathrm{P}$ \\
\hline
\end{tabular}

Means having same letter(s) in a column are not significantly different at $\mathrm{P}>0.05$ followed by DMRT. DBS= Day Before spray; DAS= Day After Spray

\section{Effect of different insecticidal treatments on population of foraging honeybee}

The results presented in Table 4 indicated that population of foraging honey bee was significantly different among the treatments after its applications at both 3 DAS and 7 DAS. At 3 DAS, among the tested insecticides Azadiractin treated plot had the maximum honeybee population $(9.24$ bees/plot/5 min) which was statistically similar to that recorded from Buprofezin ( 8.33 bees/plot $/ 5 \mathrm{~min})$ and Lufenuron $(8.13$ bees $/ 10$ plants $/ 5 \mathrm{~min})$ treated plots. The lowest honeybee population (3.43 bees/plot/5 min) was recorded in Indoxacarb treated plots. A similar trend was also observed at 7 DAS. Consequently, Indoxacarb treated 
plots had the highest reduction of honey bee population over pretreatment recorded at 7 DAS $(86.48 \%)$ indicating its higher toxicity to bee pollinators followed by Diafentiiuron. On the other hand Azadiractin 1EC treated plot had the lowest reduction (34.24\%) and this was followed by Buprofezin (40.15\%) and Lufenuron (43.61\%) treated plots. However, in untreated control plots honeybee population remained almost same showing slight increase (1.42\%) at 7 DAS.

Table 4. Effect of different insecticidal treatments on the population of foraging honeybee in mustard crop.

\begin{tabular}{|c|c|c|c|c|}
\hline \multirow{2}{*}{ Treatments } & \multicolumn{3}{|c|}{$\begin{array}{l}\text { Mean honey bee population/plot/5 } \\
\min \end{array}$} & \multirow{2}{*}{$\begin{array}{l}\text { Percent decrease (-) /increase } \\
(+) \text { of honey bee population } \\
\text { over pretreatment at } 7 \text { DAS }\end{array}$} \\
\hline & $1 \mathrm{DBS}$ & 3DAS & 7 DAS & \\
\hline Buprofezin 40SC & 14.62 & $8.33 b$ & $8.75 b$ & $(-) 40.15$ \\
\hline Indoxacarb $145 \mathrm{SC}$ & 15.32 & $3.43 \mathrm{~d}$ & $2.07 \mathrm{~d}$ & $(-) 86.48$ \\
\hline Lufenuron 5 EC & 14.10 & $8.13 b$ & $7.95 b$ & $(-) 43.61$ \\
\hline Diafenthiuron 500SC & 15.02 & $5.36 \mathrm{c}$ & $5.82 \mathrm{c}$ & $(-) 61.25$ \\
\hline Azadiractin1EC & 14.66 & $9.24 b$ & $9.64 b$ & $(-) 34.24$ \\
\hline $\begin{array}{l}\text { Untreated control } \\
\text { (water spray only) }\end{array}$ & 15.42 & $15.50 \mathrm{a}$ & $15.64 \mathrm{a}$ & $(+) 1.42$ \\
\hline $\mathrm{CV}(\%)$ & 7.10 & 10.7 & 13.11 & - \\
\hline
\end{tabular}

Means having same letter(s) in a column are not significantly different at $\mathrm{P}>0.05$ followed by DMRT. DBS= Day Before spray; DAS= Day After Spray.

\section{Effect of different insecticidal treatments on phytotoxicity and seed yield}

Phytotoxicity: It is evident from Table 5 that, phytotoxicity rating recorded was zero in all the treatments and no phytotoxic symptoms and abnormality was observed.

Seed Yield of mustard: Table 5 also indicates that there were significant variations of seed yield of mustard due to different treatments. Significantly the highest yield was obtained from Buprofezin(15.68 quintal/ ha) but this was statistically similar to Diafenthiuron $\left(1.52 \mathrm{t} \mathrm{ha}^{-1}\right)$ and Azadiractin $\left(14.76 \mathrm{t} \mathrm{ha}^{-1}\right)$ treated plots. However, the lowest yield was obtained from untreated control plots $\left(1.02 \mathrm{t} \mathrm{ha}^{-1}\right)$ followed by Lufenuron treated plots $\left(1.08 \mathrm{t} \mathrm{ha}^{-1}\right)$. Similarly, Buprofezin treated plots had the highest $(54.03 \%)$ yield increase over control followed by Diafenthiuron (49.51\%) and Azadiractin (44.99\%) treated plots. 
Table 5. Effect of different insecticidal treatments on the phytotoxicity rating and seed yield mustard crop.

\begin{tabular}{l|c|c|c}
\hline \multicolumn{1}{c|}{ Treatments } & $\begin{array}{c}\text { Phytotoxicity } \\
\text { rating }\end{array}$ & $\begin{array}{c}\text { Seed yield } \\
\left(\mathrm{t} \mathrm{ha}^{-1}\right)\end{array}$ & $\begin{array}{c}\% \text { Yield increase over } \\
\text { control }\end{array}$ \\
\hline Buprofezin 40SC & 0 & $1.57 \mathrm{a}$ & 54.03 \\
Indoxacarb 145SC & 0 & $1.23 \mathrm{~b}$ & 21.21 \\
Lufenuron 5 EC & 0 & $1.08 \mathrm{bc}$ & 6.19 \\
Diafenthiuron 500SC & 0 & $1.52 \mathrm{a}$ & 49.51 \\
Azadiractin1EC & 0 & $1.48 \mathrm{a}$ & 44.99 \\
Untreated control & 0 & $1.02 \mathrm{c}$ & - \\
(water spray only) & & & - \\
\hline
\end{tabular}

Means having same letter(s) in a column are not significantly different at $\mathrm{P}>0.05$ followed by DMRT.

\section{B. Discussion}

From the present study, it is evident that Buprofezin and Diafenthiuron showed higher effectiveness in suppressing mustard aphid as compared to other tested products. The botanical insecticide Azadiractin1EC showed slightly lower effectiveness than Buprofezin and Diafenthiuron against aphids. Many works have been done on the effectiveness of insecticides against mustard aphid mostly with conventional insecticides but a few research has been done with new generation insecticides. Rajesh et al (2013) also obtained maximum protection from mustard aphid and the highest yield by applying Thiamethoxam 25\% WDG @ $100 \mathrm{~g} / \mathrm{ha}$. Singh and Lal (2009) found that neem seed kernel extract @ 5\%, neem leaf extract @ 5\% and neem oil @ 2\% was effective in reducing the mustard aphid population. The effectiveness of botanical insecticide Azadiractin 1EC against mustard aphid is in agreement with the findings of Agarwal et al.(2001) and Nagar et al. (2012) where they obtained moderate level of effectiveness with neem products.

Considering safety to cocccinellid beetles and honeybees, Azadiractin 1EC appeared to be relatively safest insecticide. Buprofezin and Lufenuron was also safe to honeybees although slightly toxic to coccinellid beetles. On the other hand, Liafenthiuron was slightly toxic to both coccninellid beetles and foraging honeybees. Indoxacarb appeared to be slightly toxic to coccinellid beetles but highly toxic to honeybees. However, yield performance of due to application Buprofezin, Diafenthiuron and Azadiractin 1EC was statistically similar although numerically the highest yield was obtained from Buprofezin treated plots which might be due to the highest reduction of aphid due to the treatment. 
Dhingra et al. (2006) recorded that the population of coccinellid $(C$. septempunctata) was maximum under the treatment done by thermo and photo stable Tetrahydro Azadirachtin-A (THA) followed by Azadirachtin and lowest under Oxy-demeton methyl. Patel et al., (2009) observed rich activity of coccinellids in mustard in neem oil based formulation @ $0.3 \%$ and Tobacco Decoction@16.6 $\mathrm{g}^{-1}$. These studies support the present investigation.

The results of the present in studies are partly comparable to the following findings. National Registration Authority (NRA) (2001) reported that larvae of the oriental lady birds Chilocorus circumdatus) exposed to Buprofezin as $400 \mathrm{~g}$ $\mathrm{l}^{-1}$ flowable concentrate at rates $0.5 \mathrm{~g} \mathrm{l}^{-1}$ level resulted in a $60 \%$ reduction in adult lady birds. At $0.125 \mathrm{~g} \mathrm{l}^{-1}$, there were no statistical differences from the untreated controls in the number of treated larvae reaching maturity. But Buprofezin was practically nontoxic to honey bees either by contact or ingestion. Streibert et al. (1988) reported that Diafenthiuron has a relatively low toxicity to beneficial insects. But Amin et al. (2014) reported that Diafenthuron was highly toxic to $C$. septumpunctata as it showed maximum percent reduction $(78.93 \%)$ after seven days of spray application. Ahn et al. (2013) reported that Lufenuron did not show any toxic effect to honeybee and thought to be safe. Galvan et al. (2005) observed that Indoxacarb may have low acute toxicity to many predators at the suggested rates, and even reduced rates, it may reduce Harmonia axyridis population growth by affecting survival, development, and reproduction. However, Hetrick et al. (2005) observed that Indoxacarb is considered highly toxic to honeybees by contact.

Safer and effective insecticides with varying modes of action targeting aphids are needed to relieve the selection for resistance resulting from the indiscriminate application of conventional chemical insecticides throughout the mustard growing regions of Bangladesh. So, from the present study, it could be concluded that, Azadiractin 1EC (Bio neem plus) might be a viable component in mustard aphid IPM program. However, in case of severe infestation alternate spraying of Azadiractin 1EC and Buprofezin 40SC or Diafentiuron 500SC could be adopted in a well designed IPM program against mustard aphid.

\section{References}

Agarwal, N., N. Agarwal, R.K. Gupta, and S.D. Pandey. 2001. Management of mustard aphid, Lipaphis erysimi Kalt. using botanical pesticides. Flora and Fauna-Jhansi. 7(2):107-109.

Ahn, K., C. Yoon, K. Kim, S. Nam, M. Oh \& G. Kim. 2013. Evaluation of acute and residual toxicity of insecticides registered on strawberry against honeybee (Apis mellifera). Korean J. pesticide Sci. 17(3):185-192.

Ambethger. 2009. Potential of Entomopathogenic fungi in insecticide resistance management (IRM): A review. J. Biopesticides. 2(2): 177-193. 
Amin, M A., A. Hameed, M. Rizwan, M. Akmal. 2014. Effect of Different Insecticides against Insect Pests and Predators Complex on Brassica napus L., Under Field Conditions. Int. J. Scientific Res. in Environ. Sciences. 2(9): 340-345.

Bakhetia, D.R.C., B.S. Sekhon, K.S. Brar, and A.W. Ghorbandhi. 1989. Determination of economic threshold of L. erysimi on Indian Mustard. J. of Aphidol. 3: 125-134.

Bath, D. S. and D. Singh.1989. Studies on the economic threshold level of mustard aphid Lipaphis erysimi (Kaltenbach) on the radish seed crop in India. Trop. Pest manage. 35(2): 154-156.

Dhingra, S., D. Sharma, S. Sharma, J. K. Walia, G. Singh, S.Singh, B. Jayaram, and B. S. Parmar. 2006. Field appraisal of stable Neem pesticide tetrahydro Azadirectin-A against mustard aphid, Lipaphis erysimi (Kalt.). Indian J. Agril. Sci. 76(2): 111-113.

Galvan, T.L., R.L. Koch, and W.D. Hutchison. 2005. Effects of spinosad and indoxacarb on survival, development, and reproduction of the multicolored Asian lady beetle (Coleoptera: Coccinellidae). Biol. Control. 34:108-114.

Hayter, K. E and J. E. Cresswell. 2006. The importance of pollinator abundance on the dynamics and efficiency of pollination in Agricultural Brassica napus. Implications for landscape gene dispersal. J Appl. Ecol. 43:1196-1202.

Hetrick, J, W. Evans, and S. Abel. 2005. Environmental Fate and Effects Division risk assessment for proposed new uses of indoxacarb on grapes, fire ants, mole crickets, alfalfa, peanut, soybeans, Brassica leafy vegetables (Group 5), and turnip greens. PC Code 067710. U.S. EPA, Washington, D.C.

Nagar, A., S P. Singh. Y P, Singh. R. Singh. H. Meena and R. Nagar. 2012. Bio-efficacy of vegetable and organic oils, cakes and plant extracts against mustard aphid Lipaphis erysimi (Kalt.). 74(3):114-113.

National Registration Authority (NRA) for agricultural and veterinary chemicals, Canberra, Australia. 2001. Public release summary on "Evaluation of new active Buprofezin in the product Applaud insecticide. P. 42.

Patel, B. S., I. S. Patel and G. M. Patel. 2009. Evaluation of different eco-friendly modules for the management of mustard aphid, Lipaphis erysimi (Kalt.) in North Gujarat. J. Oilseed Res. 26: 679-680.

Rai, B.K.1976. Pests of oilseed crops in India and their control, Indian Council of Agricultural Research, New Delhi. Pp. 121.

Rajesh, K K., S .K. Sachan \& D.V. Singh. 2013. Bio-efficacy of Some New Insecticides Against Mustard Aphid, Lipaphis erysimi (Kalt.) and Their Effect on Coccinellid Population in Rapeseed Mustard. Int. J. Pl. Res. 26(2):159-163.

Riddiford L. M. and J. W. Truman. 1978. Biochemistry of insect hormones and insect growth regulators. In Biochemistry of Insects (Ed. by Rockstein M.), pp. 307-357. Academic Press, New York. Rohilla, H.R , P, Bhatnagar, P. R. Yadav. 2004. Chemical control of mustard aphid with newer insecticides. Inidian J. Ent. 66(1): 30-32. 
Singh, C.P. and M.N, Lal. 2009. Bio-efficacy of plant extracts against mustard aphid, Lipaphis erysimi (Kalt.) in Brassica oilseed crop. Crop Res. 37(1/3): 203-206.

Singh, K. and N.N. Singh. 2013. Preying capacity of different Established Predators of the aphid L. erysimi (Kalt.) infesting Rapeseed-mustard crop in laboratory condition. Plant Protection Sci. 49(2): 84-88.

Singhvi, S.M., Verma, N.D. and Yadava, T. P. 1973. Estimation of losses in rapeseed (B. compestris $\mathrm{L}$. var. toria) and mustard (B. juncea Cross) due to mustard aphid ( $L$. erysimi). Haryana Agri. Univ. J. of Res. 3: 5-7.

Streibert, H.P., J. Drabek, and A.Rindisbacher.1988. CGA 106630-A new type of acaricide/ insecticide for the control of the sucking pest complex in cotton and other crops. Brighton Crop Prot. Conf. (Pests and Diseases) 1:25-33. 